\title{
Are agricultural and natural sources of bio-products important for modern regenerative medicine? A review
}

\author{
Maciej Nowacki', Katarzyna Nowacka², Tomasz Kloskowski³, Marta Pokrywczyńska³, \\ Dominik Tyloch ${ }^{3}$, Marta Rasmus ${ }^{3}$, Karolina Warda ${ }^{3}$, Tomasz Drewa ${ }^{3}$ \\ 1 Chair and Department of Surgical Oncology, Nicolaus Copernicus University in Torun, Ludwik Rydygier Medical College, \\ The Prof. F. Łukaszczyk Memorial Oncology Centre in Bydgoszcz, Poland \\ ${ }^{2}$ Chair of Cosmetology and Aesthetic Dermatology, Nicolaus Copernicus University in Torun, Ludwik Rydygier Medical \\ College in Bydgoszcz, Poland \\ ${ }^{3}$ Chair of Urology, Department of Regenerative Medicine, Nicolaus Copernicus University in Torun, Ludwik Rydygier \\ Medical College in Bydgoszcz, Poland
}

Nowacki M, Nowacka K, Kloskowski T, Pokrywczyńska M, Tyloch D, Rasmus M, Warda K, Drewa T. Are agricultural and natural sources of bioproducts important for modern regenerative medicine? A review. Ann Agric Environ Med. 2017; 24(2): 207-212. doi: 10.5604/12321966.1235171

\section{Abstract}

Introduction and objectives. As tissue engineering and regenerative medicine have continued to evolve within the field of biomedicine, the fundamental importance of bio-products has become increasingly apparent. This true not only in cases where they are derived directly from the natural environment, but also when animals and plants are specially bred and cultivated for their production.

Objective. The study aims to present and assess the global influence and importance of selected bio-products in current regenerative medicine via a broad review of the existing literature. In particular, attention is paid to the matrices, substances and grafts created from plants and animals which could potentially be used in experimental and clinical regeneration, or in reconstructive procedures.

Summary. Evolving trends in agriculture are likely to play a key role in the future development of a number of systemic and local medical procedures within tissue engineering and regenerative medicine. This is in addition to the use of bio-products derived from the natural environment which are found to deliver positive results in the treatment of prospective patients.

\section{Key words}

Cellulose, plant extract, alginate, chitosan, porcine scaffold, small intestine submusocsa (SIS), bladder acellular matrix (BAM)

\section{INTRODUCTION}

For a number of years, medical treatments were mainly derived from plants, animals, and manufactured bio-products [1]. This often meant that medicine, agriculture and livestock breeding developed mutually, peaking at the turn of the 20th century [2]. At this time, there was the invention of alkaloids, glycosides and their isolation from selected plants, as well as the pharmacological development of insulin from swine and bovine pancreatic tissue [3]. These methods were later eschewed, however, in favour of the development of synthetic products, not only in medicine, but across all areas of science. Such developments can be linked to the dawn of the golden age of biomedical achievements in the field of chemistry and physics. From this time, medicine was able to develop new treatments for a number of diseases while resolving a large number of pressing issues, such positives largely outweighing the negatives incurred with such a change in approach.

The establishment of tissue engineering, however, made scientists acutely aware that innovative therapies based on stem cells, for example, would not be possible without the use of natural bio-products or specially designed biohybrids consisting of synthetic and natural biomaterials

Address for correspondence: Tomasz Kloskowski, Chair of Urology, Department of Regenerative Medicine, Nicolaus Copernicus University in Torun, Ludwik Rydygier Medical College in Bydgoszcz, Poland

M. Skłodowskiej-Curie 9, 85-094 Bydgoszcz, Poland

Tel: +48 05258560 80, Fax: +48 0525856080

E-mail: tomaszkloskowski@op.pl

Received: 9 May 2014; accepted: 11 March 2015; first published on April 2017
$[6,7]$. Such spatial matrices are good carriers of previously seeded cells and enable their precise delivery to areas where tissue regeneration is desired [8]. Since then, a number of different matrices have been evaluated such as: special biogels, amniotic membranes, spider silk, cross- linked collagenhydroxyapatite scaffolds, and many others [9].

\section{OBJECTIVE}

The aim of this study is to present a wide-ranging review of existing literature on the influence and importance of selected bio-products derived from agricultural and natural sources in current regenerative medicine. In particular, specific attention is paid to matrices, substances and grafts derived from plant and animal substrates which could be used in experimental and clinical regeneration or reconstruction procedures.

\section{MATERIALS AND METHOD}

Plant-derived materials: Cellulose. As of now, many have suggested that adequately prepared cellulose performs well as a biocompatible scaffold. It is a polysaccharide, discovered and isolated in 1838 by Anselme Payen, consisting of a linear chain of several hundred to thousands of linked D-glucose units. The most abundant organic polymer on the planet, it acts as an important component of the primary cell wall of plants, algae, fungi and bacterial biofilms. Cellulose has also 
played a significant role in medicine due to its properties, namely, biocompatibility, strength and non-degradability in the human body [10]. For example, in an animal study by Zang et al., it was successfully used as a scaffold for bone tissue engineering whereby it formed a perfect matrix with human adipose-derived stem cells (HASCs), suggesting it could be employed successfully in future cases of bone regeneration [11]. Meanwhile, a study by Singh et al. discovered properties within blends of cellulose and silk which could play a key role in the potential chondrogenesis of stem cells, without the addition of soluble growth factor TGF- $\beta$ [12]. Other studies demonstrated how a three-dimensional liver cell culture can be created using nanofibrillar cellulose hydrogel, while promise has been noted in the use of bacterial cellulose which has evidenced a very high clinical value in terms of skin tissue repair.

This is all in addition to the use of cellulose in experimental cardiac muscle procedures, the creation of prosthetic heart valves, nerve regeneration and bioartificial bladder reconstruction. However, these innovations have only been part of small individual tests and pre-trials with little statistical significance [13]. Generally, clinical trials involving cellulose have focused on its function as a component in wound dressings (Tab. 1). Most have centered on bacterial cellulose acting as an artificial skin during the use of Biofill and Bioprocess in treating burns and ulcers. Also of note has been the use of cellulose-based bio-material in Gengiflex as a means of regenerating periodontal tissues [14]. However, although cellulose is cited as a highly promising material within regenerative medicine, its application has so far been limited to pre-clinical and clinical trials, with most information about this biological substrate limited to review articles.

Table 1. Examples of cellulose-based dressings used in clinical trials

\begin{tabular}{lcc}
\hline Application & Product & $\begin{array}{c}\text { No. of } \\
\text { patients }\end{array}$ \\
\hline Wound healing & XCell & 24 \\
\hline Healing of venous ulcers & Aquacel & 281 \\
\hline Local dressing of skin lesions & Veloderm & 96 \\
\hline Haemorrhage control & Surgical (oxidized regenerated cellulose) & 39 \\
\hline
\end{tabular}

Rice paper plant. Another notable material which could be specially cultivated for regenerative medicine is the rice paper plant (Tetrapanax papyrifer). From this, an expressly designed temporary scaffold can be created, delivering positive results so far in bladder augmentation studies. Referred to in earlier studies as Japanese paper, it takes the form of a dome-shaped implant previously sprayed with nobecutane and has been used in cases of tuberculosis and interstitial cystitis. More recently, it has been suggested that it could be employed to promote bladder regeneration after cancer of this tissue. Certainly, there is the possibility of using such material as a biologically tolerated matrix in experimental cell transplantations [15].

Alginates. Alginates are another option to consider in tissue engineering applications which offer a number of advantages, such as being inexpensive and possessing biodegradable, biocompatible, non-toxic and non-immunogenic properties. They are natural polymers mainly derived from brown seaweed, but also obtainable from red seaweed and the exopolysaccharides of bacteria, including Pseudomonas and Azotobacter. These are water-soluble and consist of 1,4-linked
$\beta$-D-mannuronic acid and $\alpha$-L-guluronic acid units, their composition and molecular weight varying between algae species. Such differences can affect: viscosity, gelation, the binding affinity to cations, mechanical strength, swelling capacity and bioadhesiveness. Additionally, they can induce a range of positive effects, such as activity which is: anticholesterolaemic, antihypertensive, antidiabetic, anti-obesity, antimicrobial, anti-cancer and anti-hepatotoxicity[16].

Similar to chitosan, alginates can also be combined with other compounds which alter their composition, being produced in the form of hydrogels, microparticles, nanoparticles, powder, tablets, beads and films. Approved by the FDA, they are generally recognized as safe (GRAS), used in wound dressings (Algicell ${ }^{\oplus}$, AlgiSite $\mathrm{M}^{\mathrm{m}}$, Comfeel $^{\oplus}$ Plus, Kaltostat ${ }^{\circledR}$, Sorbsan ${ }^{\circledR}$ Tegagen $^{\text {TN}}$ ), drug administration and treatments for: heartburn (Bisodol ${ }^{\circledR}$, Asilone ${ }^{\circledR}$ ), acid reflux (Gaviscon ${ }^{\circledast}$ ), pressure sores, reflux suppression and weight loss [16]. This is in addition to the common application of alginate gels during tissue engineering within in vitro and in vivo cell cultures [17]. Moreover, a number of clinical trials have utilized alginates, detailed in Table 2.

Table 2. Examples of alginate and chitosan utilization in clinical trials

\begin{tabular}{|c|c|c|}
\hline Application & Form & $\begin{array}{c}\text { No. of } \\
\text { patients }\end{array}$ \\
\hline \multicolumn{3}{|l|}{ Alginate } \\
\hline Pressure sores & Alginate dressing & 14 \\
\hline Post-operative intrauterine adhesion & $\begin{array}{l}\text { Alginate } \\
\text { carboxymethylcellulose } \\
\text { hyaluronic acid gel }\end{array}$ & 192 \\
\hline Reflux suppression & Liquid (Gaviscon ${ }^{\circledast}$ ) & 20 \\
\hline Weight loss & Powder & 96 \\
\hline Non-erosive reflux disease & Liquid & 76 \\
\hline Skin graft & $\begin{array}{l}\text { Calcium alginate dressing } \\
\text { (Kaltostat }^{\oplus} \text { ) }\end{array}$ & 36 \\
\hline Burn wounds & $\begin{array}{l}\text { Silver alginate dressing } \\
\text { (Askina Calgitrol } \mathrm{Ag}^{\oplus} \text { ) }\end{array}$ & 65 \\
\hline Wounds after haemorrhoidectomy & Fibre dressing $\left(\right.$ Sorbsan $\left.^{\oplus}\right)$ & 50 \\
\hline \multicolumn{3}{|l|}{ Chitosan } \\
\hline Chronic Peridontitis & Chitosan gel & 15 \\
\hline Chronic Peridontitis & $\begin{array}{l}\text { Chitosan gel alone or with } \\
\text { demiralized bone matrix or } \\
\text { collagenous membrane }\end{array}$ & 20 \\
\hline Plastic surgery & $\begin{array}{l}\text { Soft pads of freeze-dried } \\
\mathrm{N} \text { - carboxybutyl chitosan }\end{array}$ & \\
\hline Wound healing & Chitosan dressing & 20 \\
\hline Wound healing & $\begin{array}{l}\text { Chitosan membrane } \\
\text { (mesh or non-mesh form) }\end{array}$ & 20 \\
\hline Haemostasis and wound healing & Chitosan/dextran gel & 40 \\
\hline Rosacea & Cream & 42 \\
\hline Cartilagle repair & BST-CarGel & 80 \\
\hline $\begin{array}{l}\text { Inhibition of enamel demineralization } \\
\text { around orthodontic brackets }\end{array}$ & Dentifrice & 16 \\
\hline Anti-microbial properties & Chitosan spray & 29 \\
\hline Obesity & Capsules & 34 \\
\hline Obesity & Capsules & 12 \\
\hline Hepatocellular carcinoma & $\begin{array}{l}\text { Holmium-166-chitosan } \\
\text { complex }\end{array}$ & 54 \\
\hline Chronic renal failure & Tablets & 80 \\
\hline Bacteria growth inhibition & Chewing gum & 50 \\
\hline
\end{tabular}


Plant-derived human collagen scaffolds (PDHC). The bestknown among plant-derived solutions in the areas of tissue engineering and regenerative medicine are projects related to experimental dermatological procedures and modern methods of treating various types of wounds [18]. Here, the studies often refer to plant-derived human collagen scaffolds (PDHC) such as soy, which can be used in the development of engineered skin [19]. These are also known as electrospun soy protein-based scaffolds, partially making reference to the technical process of electrospining which is used to produce such matrices [20]. Used as carriers for different types of cultured skin cells, such as fibroblasts and melanocytes, they are considered one of the better biomaterials available [21]. This is on account of both the relatively low risk of allergic response or disease transmission they induce, and their strong biological properties whereby they promote the proper maturation and differentiation of cultivated cells in experimental models.

Plant extracts. Other applications of plant-derived products are also connected with the use of specific extracts, whether to encourage cell growth or to stimulate differentiation. Admittedly, there is limited research here, but recently published data offers hope that novel and innovative regenerative treatment procedures could be developed. For example, positive effects have been noted in the use of different plant extracts within in vitro and in vivo studies whereby they have been found to have helped induce apoptosis during the treatment of acute lymphoblastic leukaemia, as well as possessing potential antimicrobial properties [22]. Further details showing the potential use of specific plant extracts in innovative regenerative medicine are shown in Table 3.

Table 3. Specific plant extracts which could be used in innovative regenerative medicine

\begin{tabular}{ll}
\hline Plant extract & Potential effects \\
\hline $\begin{array}{l}\text { Extract of Geum japonicum } \\
\text { (EGJ) }\end{array}$ & $\begin{array}{l}\text { Effective cardiogenic differentiation of } \\
\text { mesynchymal stem cells (MSCs) and additional } \\
\text { dual effect on angiogenesis and myogenesis } \\
\text { during in-vivo repair model of infracted } \\
\text { myocardium. }\end{array}$ \\
\hline $\begin{array}{l}\text { Withanolide A (WL-A) } \\
\text { extract isolated from Indian } \\
\text { herbal drug Ashwagandha } \\
\text { (Withania somnifera) }\end{array}$ & $\begin{array}{l}\text { In vitro and in vivo recovery of neuritic atrophy and } \\
\text { synaptic loss. }\end{array}$ \\
\hline $\begin{array}{l}\text { Extract of Stewartia koreana } \\
\text { leaves (SKE) }\end{array}$ & $\begin{array}{l}\text { In-vivo stimulation of proliferation and migration } \\
\text { processes of human endothelial cells with one } \\
\text { step neovasculization induction }\end{array}$ \\
\hline Extract of Shuanghuangbu & $\begin{array}{l}\text { A specially designed Shuanghuangbu-scaffold } \\
\text { extract could reinforce proliferation activity of } \\
\text { periodontal ligament cells (PDLCs). }\end{array}$ \\
\hline Blueberry extract & $\begin{array}{l}\text { In-vivo animal dietary supplementation with } \\
\text { blueberry extract enhances survival of intraocular } \\
\text { hippocampal transplants }\end{array}$ \\
\hline Ethanol extract of Fructus & $\begin{array}{l}\text { EFLL extract enhances the osteogenic } \\
\text { differentiation of mesynchymal stem cells (MSCs) }\end{array}$ \\
\hline Ligustri Lucidi (EFLL) &
\end{tabular}

Animal-derived matrices: Chitin-derived scaffolds. Moving on to the possibilities created by animal-derived matrices in regenerative medicine, chitin is the second most abundant natural polymer and is found in the shells of crustaceans, the cuticles of insects, and the cell walls of fungi and yeast. It is mainly sourced commercially from the shells of crabs and shrimps, a by-product of the seafood industry [23]. Bearing bacteriostatic and fungistatic functions, chitin's main drawback is its insolubility in water and other common solvents.

Through alkaline deacetylation, the cationic polysaccharyde, chitosan, is created from it, a $\beta$-1,4-linked polymer of glucosamine (2-amino-2-deoxy- $\beta$-D-glucose) but with a smaller amount of $\mathrm{N}$-acetyloglucosoamine. It possesses additional properties, such as biocompatibility, biodegradability, haemostatic action and mucoadhesion. Although insoluble in water, it can be solubilized in a dilute aqueous acid solution. Furthermore, chitosan has FDA approval as a wound dressing while also being permitted as a food supplement in Japan, Italy and Finland, and is Generally Recognized As Safe (GRAS) in food within the USA [24, 25].

Chitosan, which can be produced at varying molecular weights and degrees of deacetylation, allows the simple creation of differently shaped scaffolds, taking the form of: tubes, membranes, gels, nanofibers, microparticles, nanoparticles, foams, beads, powder, films and porous materials [26]. These are mainly produced via lyophilisation which allows the production of biomaterials with a controlled pore size. Combinations can also be made with other substances, such as collagen, heparin, hialuronic acid, gelatin or alginate, while the addition of functional groups such as ammonium or carboxymethyl can enhance its properties. Meanwhile, electrospining methods allow for chitosan to resemble an extracellular matrix (ECM) in structure, making this material a promising source for tissue engineering applications [27]. Additionally, its chelating properties allow the possible formation of a complex with calcium, cobalt, zinc and nickel, which could improve scaffold strength and stiffness, as well as levels of mineralization and vascularization [28]. Such a compound has already been used in wound healing in addition to skin, cartilage, bone, nerve, periodontal tissue and liver regeneration [25]. Furthermore, it has proved a very reliable material for delivering drugs and filtering water and air [25]. More examples of chitosan's use in clinical practice are presented in Table 2.

Porcine-derived vascular and dermal scaffolds. 'Waste materials' from animal slaughterhouses, such as porcine skin or arterial vessels, have also been noted as enabling the creation of high quality bio-natural matrices which deliver significant results [29]. Decellularization procedures carried out on such materials can be adapted to create optimal results, notably via the creation of acellular matrices [30].

In a representative group of in vivo studies, it has been shown that a decellularized vessel matrix previously seeded with mesenchymal stem cells (MSC) may be a better option than standard polypropylene mesh in treating large abdominal wall injuries, or in ventral hernia repair surgery. These studies also indicate that such products possess excellent mechanical and biological properties [31]. Figure 1, taken from one such in-vivo experiment, shows a sample of a swine-derived vessel graft used for the reconstruction of an abdominal wall in a rat model. Another swine-derived bio-product is the skin, commonly referred to as a porcine acellular dermal graft. With favourable properties being observed within different types of ventral hernia surgery, this process is seen as potentially revolutionizing standard skin replacement procedures performed after burns or degloving injuries which expose tendons or bones. In 


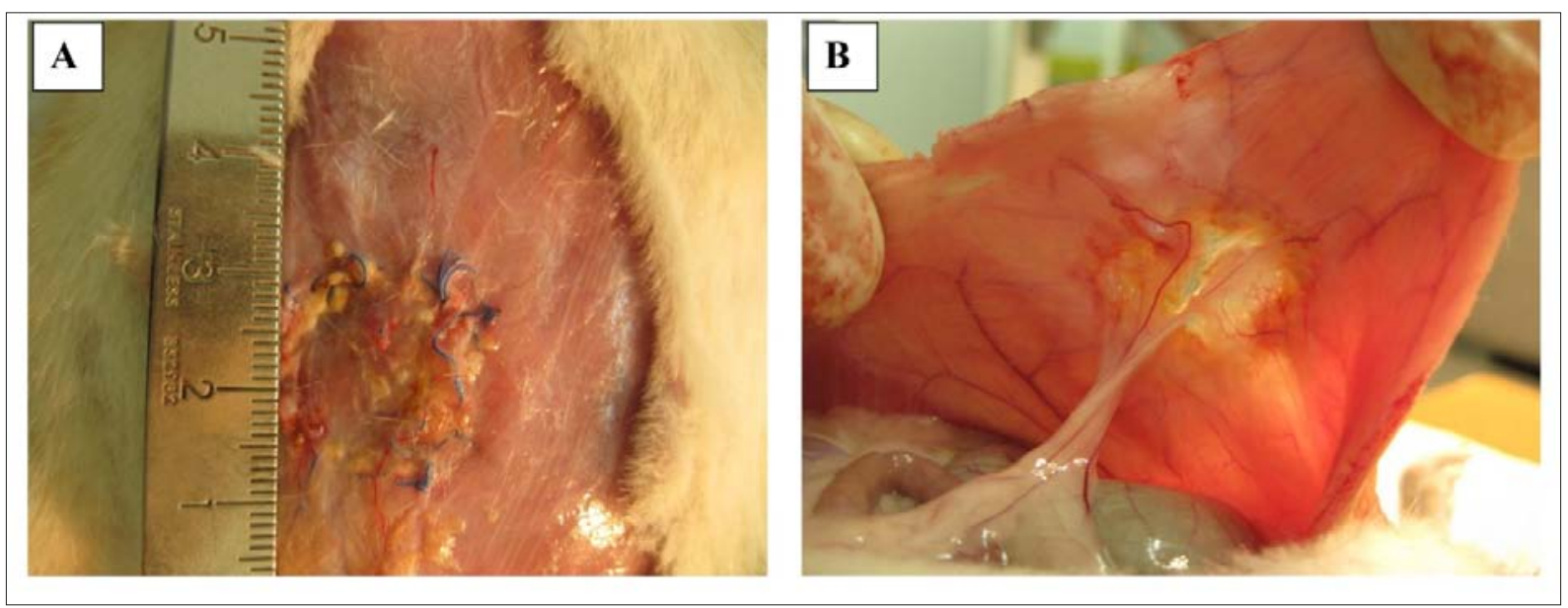

Figure 1. Example of a swine-derived vessel graft, previously seeded with mesynchymal stem cells (MSC), used in an experimental reconstruction of an abdominal wall in a rat model.

A - Macroscopic view of implemented acellular swine-derived graft previously seeded with MSC cells.

B - Clearly visible neo-vascularization and integration between the porcine acellular graft and rat abdomen wall tissues.

particular, it is seen as viable in fully personalized treatments where there is a rapid need to perform life-saving surgical procedures [32]. Some specific examples of porcine decellularized dermal graft utilization in clinical and experimental practice are presented in Table 4.

Table 4. Examples of porcine decellularized dermal graft and small intestine submucosa (SIS) utilization in clinical and experimental practice

\begin{tabular}{|c|c|}
\hline Application & Product \\
\hline \multicolumn{2}{|l|}{ Porcine dermal graft } \\
\hline Abdominal sacrocolpopexy & Pelvicol@ (CR BARD, Murray Hill,NJ) \\
\hline $\begin{array}{l}\text { Treatment of stress urinary incontinence } \\
\text { in women }\end{array}$ & Pelvicol@ (CR BARD, Murray Hill,NJ) \\
\hline Rectocele repair & Pelvicol@ (CR BARD, Murray Hill,NJ) \\
\hline $\begin{array}{l}\text { Surgical implant in incisional and ventral } \\
\text { hernia repair }\end{array}$ & Permacol $^{\mathrm{TM}}$ (covidien) \\
\hline $\begin{array}{l}\text { Extracellular matrix patch in malignant and } \\
\text { non-malignant chest wall reconstruction in } \\
\text { thoracic surgery. }\end{array}$ & $\begin{array}{l}\text { XCM Biologic Tissue Matrix } \odot \\
\text { (Depuy Synthes) }\end{array}$ \\
\hline Implant-based breast reconstruction & $\begin{array}{l}\text { Strattice }{ }^{\mathrm{TM}} \text { Reconstructive Tissue } \\
\text { Matrix }\end{array}$ \\
\hline Burn wounds & Permacol $^{\mathrm{TM}}$ (covidien) \\
\hline \multicolumn{2}{|l|}{ Small Intestine Submucosa (SIS) } \\
\hline $\begin{array}{l}\text { Surgical repair of damaged or missing } \\
\text { musculotendinous tissue }\end{array}$ & CuffPatch $^{\mathrm{TM}}$ (Arthrotek) \\
\hline $\begin{array}{l}\text { In neurosurgical procedures to expand or } \\
\text { replace dura mater resected during surgery }\end{array}$ & $\begin{array}{l}\text { Durasis }^{\oplus} \text { (Cook Biotech, Spencer, } \\
\text { Indiana) }\end{array}$ \\
\hline Surgical correction of Peyronie's disease & $\begin{array}{l}\text { Stratasis }{ }^{\oplus} \text { (Cook Biotech, Spencer, } \\
\text { Indiana) }\end{array}$ \\
\hline Abdominal wall reconstruction & $\begin{array}{l}\text { Surgisis }{ }^{\oplus} \text { (Cook Biotech, Spencer, } \\
\text { Indiana) }\end{array}$ \\
\hline Diabetic foot ulcer therapy & Oasis $^{\oplus}$ (Depuy Synthes) \\
\hline $\begin{array}{l}\text { Augmentation and repair of large or } \\
\text { complex tendon tears }\end{array}$ & Restore $^{T M}$ (Depuy, Warsaw, IN), \\
\hline
\end{tabular}

Small Intestinal Submucosa (SIS). Another prominent material studied is Small Intestinal Submucosa (SIS), a natural biomaterial which is typically obtained from porcine small intestines. Initially, this was obtained via the mechanical removal of the mucosa, strata of muscle fibres and serosa, the resulting membrane being about $100 \mu \mathrm{m}$ thick and composed of submucosa alongside the remains of the basal membrane of the tunica mucosa [33]. At present, however, SIS is primarily acquired through decellularization of the small intestine, the removal of cells allowing immunologically neutral biomaterial to be obtained which can be used in a variety of tissue engineering and regenerative medicine applications.

Thereafter, a number of methods can be employed to prepare an acellular matrix: physical, chemical and enzymatic [34]. The first has proven ineffective at removing cells when applied in isolation, requiring freezing and thawing, mechanical scraping, agitation and sonication [35]. In contrast, chemical techniques appear more efficient, mainly involving the use of detergents, such as Triton X-100, Triton X-200, sodium dodecyl sulfate (SDS) and 3-[(3-cholamidopropyl) dimethylammonio]-1-propanesulfonate (CHAPS) [36]. Then there are enzymatic methods of decellularization which are based on the use of nucleases, proteases and calcium chelating agents [37]. Additionally, antibiotics and protease inhibitors are used respectively to eliminate the presence of bacteria and protect the native layer of collagen while proteases are being applied. Overall, however, the best results are achieved using a combination of the methods outlined above.

In any case, once the acellular matrix is created, it primarily contains collagen (types I, III, IV and VI) as well as glycoproteins (laminin and fibronectin), glycosaminiglycans, proteoglycans and growth factors, such as transforming growth factor- $\beta$ (TGF- $\beta$ ), basic fibroblast growth factor (b-FGF) and vascular endothelial growth factor (VEGF) [38]. SIS scaffolds produced on an industrial scale also comprise several layers in contrast to native single-layer forms. The commercially available tissue is outlined in Table 4.

Primarily, this widespread use of SIS as an extracellular matrix in regenerative medicine is due to its structural and biochemical properties. As well as being used in a variety of applications as a cell-seeded or un-seeded collagen matrix, it has also shown great potential to regenerate urogenital tissues and organs, including the urinary bladder, urethra, tunica albuginea and vagina [39, 40]. Various studies have also assessed the suitability of SIS as a scaffold for the regeneration of heart, bone, nerve, tendon, hernia and soft tissue [41, 42]. 
Bladder acellular matrix (BAM). Moving on to another material, bladder acellular matrix (BAM) is a natural scaffold obtained from the urinary bladder by the mechanical or chemical removal of cellular components. Here, the process of decellularization is similar to that of small intestinal submucosa. Until now, it has mainly been used for urethra and bladder reconstruction [43], the extracellular matrix of the urinary bladder wall providing an excellent environment for the growth, proliferation and differentiation of cells. The three-dimensional structure of BAM then allows the attachment of cells to itself, both urothelial (UCs) and smooth muscle cells (SMCs) proliferating very well within it, the rate of UCs being three times as high as when SIS is utilized $[44,45]$. Additionally, BAM contains many growth factors, such as VEGF (Vascular Endothelial Growth Factor), PDGFBB (Platelet-Derived Growth Factor-BB), KGF (Keratinocyte Growth Factor), TGF $\beta 1$ (Transforming Growth Factor- $\beta 1$ ), IGF (Insulin-like Growth Factor), bFGF (basic Fibroblast Growth Factor), EGF (Epidermal Growth Factor), TGF- $\beta$ (Transforming Growth Factor- $\beta$ ) and BMP4 (Bone Morphogenetic Proteins 4), which stimulate the process of regeneration [46]. Giving it strength and flexibility are high volumes of collagen and elastin alongisde the fact BAM is considered a safe, biocompatible biomaterial which integrates well with the tissues after implantation while not being immunogenic. It is also available commercially in the form of products such as MatriStem (ACell) which are mainly used for the treatment of acute and chronic wounds.

\section{CONCLUSIONS}

The presented review has looked at a number of bio-products and their different experimental applications within tissue engineering and regenerative medicine. All of those discussed are the result of modern agricultural techniques or taken directly taken from the natural environment. By and large, they are a good example of how both the current slaughter and meat processing industry and targeted plant cultivation are fully convergent in their production capacities with the development of innovative medicine. Among the most significant of these has been the use of different types of cells within tissue engineering, progenitor stem cells being the most prominent, referred to in $85 \%$ of the relevant literature [47]. Nonetheless, deficiencies are evident in current standard procedures related to stem cell cultivation and their application in both experimental and clinical cases, further innovations being required to make them more efficient. Such problems are largely connected with biological issues whereby technological, chemical and physical solutions have been designed with fully synthetic and other artificial products in mind, whether they are nonbiological cell matrices or cell grafts. Parallel to this has been the 'bio-modulation' of different metabolic or physiological functions during in vitro and in vivo procedures [48]. Nevertheless, there is enough evidence to conclude that continuing advances in agriculture are likely to play a key role in the future development of numerous systemic and local medical procedures in the fields of tissue engineering and regenerative medicine. Within both, agriculture has had a continually increasing influence which could lead to the biotechnological modification of methods in plant cultivation and livestock breeding to obtain specially designed and targeted bio-products $[49,50]$. Similarly, materials and substances derived from the natural environment can also be expected to have a significant impact, current developments suggesting better treatment being applied to prospective patients in the future.

\section{REFERENCES}

1. Ji HF, Li XJ, Zhang HY. Natural products and drug discovery. Can thousands of years of ancient medical knowledge lead us to new and powerful drug combinations in the fight against cancer and dementia? EMBO Rep. 2009; 10(3): 194-200.

2. Petrovska BB. Historical review of medicinal plants' usage. Pharmacogn Rev. 2012; 6(11): 1-5.

3. Rosenfeld L. Insulin: discovery and controversy. Clin Chem. 2002; 48(12): 2270-2288.

4. Pushkar D, Kasyan G, Gvozdev M, Sosnowski R. Analysis of 1,000 cases of synthetic midurethral slings used for treatment of female urinary incontinence - a single-center experience. Cent European J Urol. 2011; 64(4): 243-251.

5. Nowacki M, Adamowicz J, Pietkun K, Olkowska J, Kloskowski T, Bajek A, et al. Non-alcoholic beverages, unknown influence on cell proliferation - an in vitro study. Ann Agric Environ Med. 2014; 21(1): 113.

6. Adamowicz J, Kowalczyk T, Drewa T. Tissue engineering of urinary bladder - current state of art and future perspectives. Cent European J Urol. 2013; 66(2): 202-206.

7. Kloskowski T, Kowalczyk T, Nowacki M, Drewa T. Tissue engineering and ureter regeneration: is it possible? Int J Artif Organs. 2013; 36(6): 392-405.

8. Spector M. The tissue engineer's toolbox manifesto. Biomed Mater. 2014; 9(1): 010201

9. Panda NN, Jonnalagadda S, Pramanik K. Development and evaluation of cross-linked collagen-hydroxyapatite scaffolds for tissue engineering. J Biomater Sci Polym Ed. 2013; 24(18): 2031-2044.

10. Bačáková L, Novotná K, Pařízek M. Polysaccharides as Cell Carriers for Tissue Engineering: the Use of Cellulose in Vascular Wall Reconstruction. Physiol Res. 2014; 63(Suppl. 1): S29-S47.

11. Fu L, Zhang J, Yang G. Present status and applications of bacterial cellulose-based materials for skin tissue repair. Carbohydr Polym. 2013; 92(2): 1432-1442.

12. Zang S, Zhuo Q, Chang X, Qiu G, Wu Z, Yang G. Study of osteogenic differentiation of human adipose-derived stemcells (HASCs) on bacterial cellulose. Carbohydr Polym. 2014; 104: 158-165.

13. Shah N, Ul-Islam M, Khattak WA, Park JK. Overview of bacterial cellulose composites: A multipurpose advanced material. Carbohydr Polym. 2013; 98(2): 1585-1598.

14. Novaes AB, Novaes AB, Grisi MFM, Soares UN, Gabarra F. Gengiflex, an Alkali-Cellulose Membrane for GTR: Histologic Observations. Braz Dent J. 1993; 4(2): 65-71.

15. Pokrywczynska M, Adamowicz J, Sharma AK, Drewa T. Human urinary bladder regeneration through tissue engineering - An analysis of 131 clinical cases. Exp Biol Med (Maywood). 2014; 239(3): 264-271.

16. Bidarra SJ, Barrias CC, Granja PL. Injectable alginate hydrogels for cell delivery in tissue engineering. Acta Biomater. 2014; 10(4): 1646-1662.

17. Aroguz AZ, Baysal K, Adiguzel Z, Baysal BM. Alginate/Polyoxyethylene and Alginate/Gelatin Hydrogels: Preparation, Characterization, and Application inTissue Engineering. Appl Biochem Biotechnol. 2014; 173(2): 433-448.

18. Kemp P. History of regenerative medicine: looking backwards to move forwards. Regen Med. 2006; 1(5): 653-669.

19. Lin L, Perets A, Har-El YE, Varma D, Li M, Lazarovici P, et al. Alimentary 'green' proteins as electrospun scaffolds for skin regenerative engineering. J Tissue Eng Regen Med. 2013; 7(12): 994-1008.

20. Shin M, Yoshimoto H, Vacanti JP. In vivo bone tissue engineering using mesenchymal stem cells on a novel electrospun nanofibrous scaffold. Tissue Eng. 2004; 10(1-2): 33-41.

21. Czajkowski R, Pokrywczynska M, Placek W, Zegarska B, Tadrowski T, Drewa T. Transplantation of cultured autologous melanocytes: hope or danger? Cell Transplant. 2010; 19(5): 639-643.

22. Farias DF, Souza TM, Viana MP, Soares BM, Cunha AP, Vasconcelos IM, et al. Antibacterial, antioxidant, and anticholinesterase activities of plant seed extracts from Brazilian semiarid region. Biomed Res Int. 2013; 2013: 510736 . 
23. Jayakumar R, Prabaharan M, Nair SV, Tamura H. Novel chitin and chitosan nanofibers in biomedical applications. Biotechnol Adv. 2010; 28(1): 142-150.

24. Chandy T, Sharma CP. Chitosan-as a biomaterial. Artif Cells Nanomedicine Biotechnol. 1990; 18(1): 1-24.

25. Illum, L. Chitosan and its use as a pharmaceutical excipient. Pharm Res. 1998; 15(9): 1326-1331.

26. Sliva SS, Mano JF, Reis RL. Potential applications of natural origin polymer-based systems in soft tissue regeneration. Crit Rev Biotechnol. 2010; 30(3): 200-221.

27. Drewa T, Adamowicz J, Lysik J, Polaczek J, Pielichowski J. Chitosan scaffold enhances nerve regeneration within the in vitro reconstructed bladder wall: an animal study. Urol Int. 2008; 81(3): 330-334.

28. Adewuyi S, Kareem KT, Atayese AO, Amolegbe SA, Akinremi CA. Chitosan-cobalt (II) and nickel (II) chelates as antibacterial agents. Int J Biol Macromol. 2011; 48(2): 301-303.

29. Xiong Y, Chan WY, Chua AW, Feng J, Gopal P, Ong YS, et al. Decellularized porcine saphenous artery for small-diameter tissueengineered conduit graft. Artif Organs. 2013; 37(6): E74-87.

30. Fitzpatrick JC, Clark PM, Capaldi FM. Effect of decellularization protocol on the mechanical behavior of porcine descending aorta. Int J Biomater. 2010; 2010.

31. Hsu PW, Salgado CJ, Kent K, Finnegan M, Pello M, Simons R, et al. Evaluation of porcine dermal collagen (Permacol) used in abdominal wall reconstruction. J Plast Reconstr Aesthet Surg. 2009; 62(11): 14841489.

32. Smart NJ, Bryan N, Hunt JA, Daniels IR. Porcine dermis implants in soft-tissue reconstruction: current status. Biologics. 2014; 8: 83-90.

33. Badylak SF, Lantz GC, Coffey A, Geddes LA. Small intestinal submucosa as a large diameter vascular graft in the dog. J Surg Res. 1989; 47(1): 74-80.

34. Gilbert TW, Sellaro TL, Badylak SF. Decellularization of tissues and organs. Biomaterials. 2006; 27(19): 3675-3683.

35. Hung SH, Su CH, Lee FP, Tseng H. Larynx decellularization: combining freeze-drying and sonication as an effective method. J Voice. 2013; 27(3): 289-294.

36. Dahl SL, Koh J, Prabhakar V, Niklason LE. Decellularized native and engineered arterial scaffolds for transplantation. Cell Transplant. 2003; 12(6): 659-666.

37. Luo JC, Chen W, Chen XH, Qin TW, Huang YC, Xie HQ, et al. A multistep method for preparation of porcine small intestinal submucosa (SIS). Biomaterials. 2011; 32(3): 706-713.
38. Brown B, Lindberg K, Reing J, Stolz DB, Badylak SF. The basement membrane component of biologic scaffolds derived from extracellular matrix. Tissue Eng. 2006; 12(3): 519-526.

39. Nakatsu H, Ueno T, Oga A, Nakao M, Nishimura T, Kobayashi S, et al. Influence of mesenchymal stem cells on stomach tissue engineering using small intestinal submucosa. J Tissue Eng Regen Med. 2013; 9(3): 296-304.

40. Shukla D, Box GN, Edwards RA, Tyson DR. Bone marrow stem cells for urologic tissue engineering, World J Urol. 2008; 26(4): 341-349.

41. Zhou Y, Yan Z, Zhang H, Lu W, Liu S, Huang X, et al. Expansion and delivery of adiposederived mesenchymal stem cells on three microcarriers for soft tissue regeneration. Tissue Eng Part A. 2011; 17(23-24): 2981-2997.

42. Drewa T, Joachimiak R, Kaznica A, Sarafian V, Pokrywczynska M. Hair stem cells for bladder regeneration in rats: preliminary results. Transplant Proc. 2009; 41(10): 4345-4351.

43. Li CL, Liao WB, Yang SX, Song C, Li YW, Xiong YH, et al. Urethral reconstruction using bone marrow mesenchymal stem cell- and smooth muscle cell-seeded bladder acellular matrix. Transplant Proc. 2013; 45(9): 3402-3407.

44. Brown AL, Brook-Allred TT, Waddell JE, White J, Werkmeister JA, Ramshaw JA, Bagli DJ, Woodhouse KA, Bladder acellular matrix as a substrate for studying in vitro bladder smooth muscle-urothelial cell interactions, Biomaterials. 2005 Feb; 26(5): 529-43.

45. Davis NF, Callanan A, McGuire BB, Flood HD, McGloughlin TM. Evaluation of viability and proliferative activity of human urothelial cells cultured onto xenogenic tissue-engineered extracellular matrices, Urology. 2011; 77(4): 1007.e1-7.

46. Chun SY, Lim GJ, Kwon TG, Kwak EK, Kim BW, Atala A, et al. Identification and characterization of bioactive factors in bladder submucosa matrix, Biomaterials. 2007; 28(29): 4251-4256.

47. Bajek A, Drewa T, Joachimiak R, Marszałek A, Gagat M, Grzanka A. Stem cells for urinary tract regeneration. Cent European J Urol. 2012; 65(1): 7-10.

48. Polak DJ. Regenerative medicine. Opportunities and challenges: a brief overview. J R Soc Interface. 2010; 7(Suppl 6): S777-781.

49. Mano JF, Silva GA, Azevedo HS, Malafaya PB, Sousa RA, Silva SS, et al. Natural origin biodegradable systems in tissue engineering and regenerative medicine: present status and some moving trends. J R Soc Interface. 2007; 4(17): 999-1030.

50. Nowacki M, Kloskowski T, Pokrywczyńska M, Nazarewski L, Jundziłł A, Pietkun $\mathrm{K}$, et al. Is regenerative medicine a new hope for kidney replacement? J Artif Organs. 2014; 17(2): 123-134. 